\begin{tabular}{|c|c|c|c|c|c|}
\hline JRL & Vol. 12 & No. 2 & Hal : 136-154 & $\begin{array}{c}\text { Jakarta, } \\
\text { Desember 2019 }\end{array}$ & $\begin{array}{c}\text {-ISSN : 2085.38616 } \\
\text { e-ISSN : 2580-0442 }\end{array}$ \\
\hline
\end{tabular}

\title{
WASTE EXCHANGE LIMBAH ONGGOK TAPIOKA DENGAN PROSES BIOLOGIK UNTUK PERIPTAAN POLYUNSATURATED FATTY ACID
}

\author{
Nurul Ummi ${ }^{1}$, Dwindrata B. Aviantara ${ }^{2}$ \\ ${ }^{1}$ Teknik Industri - Universitas Sultan Ageng Tirtayasa \\ ${ }^{2}$ Pusat Teknologi Lingkungan - BPPT \\ Gd. 820 Geostech PUSPIPTEK Serpong, 15314, Provinsi Banten \\ Email : aviantara@rocketmail.com
}

\begin{abstract}
Abstrak
Onggok merupakan sisa dari proses penyarian singkong dengan cara pengepresan dalam produksi tapioka. Komposisinya yang didominasi oleh pati dan serat kasar membuka peluang pemanfaatan limbah onggok sebagai medium fermentasi padat untuk produksi PUFA. Periptaan PUFA secara biologik lazim menggunakan kapang Aspergillus. Aspergillus mampu menghasilkan asam lemak menyerupai asam lemak yang diperoleh dari minyak kelapa sawit, yakni linolenat dan linoleat. Kapang Aspergillus juga dikenal memiliki kemampuan mendegradasi bahan organik termasuk limbah sehingga berpotensi untuk diterapkan dalam mengolah limbah onggok, ampas tahu, molase serta dedak padi. Dengan memanfaatkan onggok sebagai media fermentasi padat seta sumber karbon dalam produksi PUFA maka terdapat potensi pengurangan biaya operasional dalam produksi PUFA. Hal ini akan meningkatkan keunggulan daya saing dalam produksi PUFA termasuk meningkatnya aspek kinerja dari sudut pandang lingkungan. Memanfaatkan limbah sebagai bahan baku dalam proses produksi merupakan penerapan nyata konsep waste to product atau waste exchange dalam membangun industri proses yang selaras dengan kaidah Sustainanle Consumption and Production.
\end{abstract}

kata kunci : onggok, asam lemak tak jenuh, fermentasi padat, waste exchange, sustainable consumption and production, kualitas lingkungan 


\title{
TAPIOCA WASTE EXCHANGE THROUGH BIOLOGICAL PROCESS FOR POLYUNSATURATED FATTY ACID SYNTHESE
}

\begin{abstract}
Onggok is a solid waste generated from casava extraction during tapioca production. Its composition is dominated by starch and coarse fiber as such opening possibility to use it as a solid state medium for PUFA production. Aspergillus fungi is commonly used in biological synthese of PUFA. Aspergillus capable of producing a high proportion of unsaturated fatty acid that is similar to obtain from palm oil, i.e. linolenic and linoleic acids. Aspergillus fungi is also recognised to have ability in degrading organic materials including wastes. Thus, such the fungi is potentially be applied in onggok, tofu waste, molasses and rice bran. By utilizing onggok as solid state fermentation medium as well as carbon source in PUFA production then operational cost of PUFA production is reduced. This will improve competitiveness in PUFA production as well as will enhance environmental performance point of view. Waste utilization as raw materials in production process is the real implemantation of waste to product or waste exchange concept for the purpose of establishment of process industries that conform to Sustainable Consumption and Production paradigm.
\end{abstract}

keywords : onggok, unsaturated fatty acid, solid state fermentation, waste exchange, sustainable consumption and production, environmental quality 


\section{PENDAHULUAN}

Onggok merupakan sisa dari proses penyarian (extraction) singkong dengan cara pengepresan dalam produksi tapioka dengan tahapan sebagaimana disajikan pada Gambar 2. Secara fisik onggok berupa padatan seperti pada tampak Gambar 1 (AgroBisnisInfo.com 2015). Berdasarkan aras (level) air dalam onggok maka terdapat dua kelompok onggok yaitu onggok basah dan onggok kering. Onggok basah biasanya dimanfaatkan dalam pakan ternak sapi. Sedangkan onggok kering dimanfaatkan sebagai bahan baku dalam pembuatan saos, kecap, perekat kertas, atau obat nyamuk. Daerah yang menjadi sentra industri tapioka Indonesia adalah Bogor, Sukabumi, Purbalingga, Pati, Wonogiri serta Lampung. Komposisi kimia onggok didominasi oleh pati serta serat kasar sebagaimana disajikan pada Tabel 1 (Mustika dkk. 2009). Suatu industri tapioka berkapasitas 700 ton/hari dapat menghasilkan limbah onggok sebesar 175 ton/hari $(25 \%$ dari bahan baku). Berdasarkan komposisi limbah onggok tersebut terdapat potensi pemanfaatan limbah onggok dalam produksi polyunsaturated fatty acid (PUFA) yang memiliki nilai ekonomik.

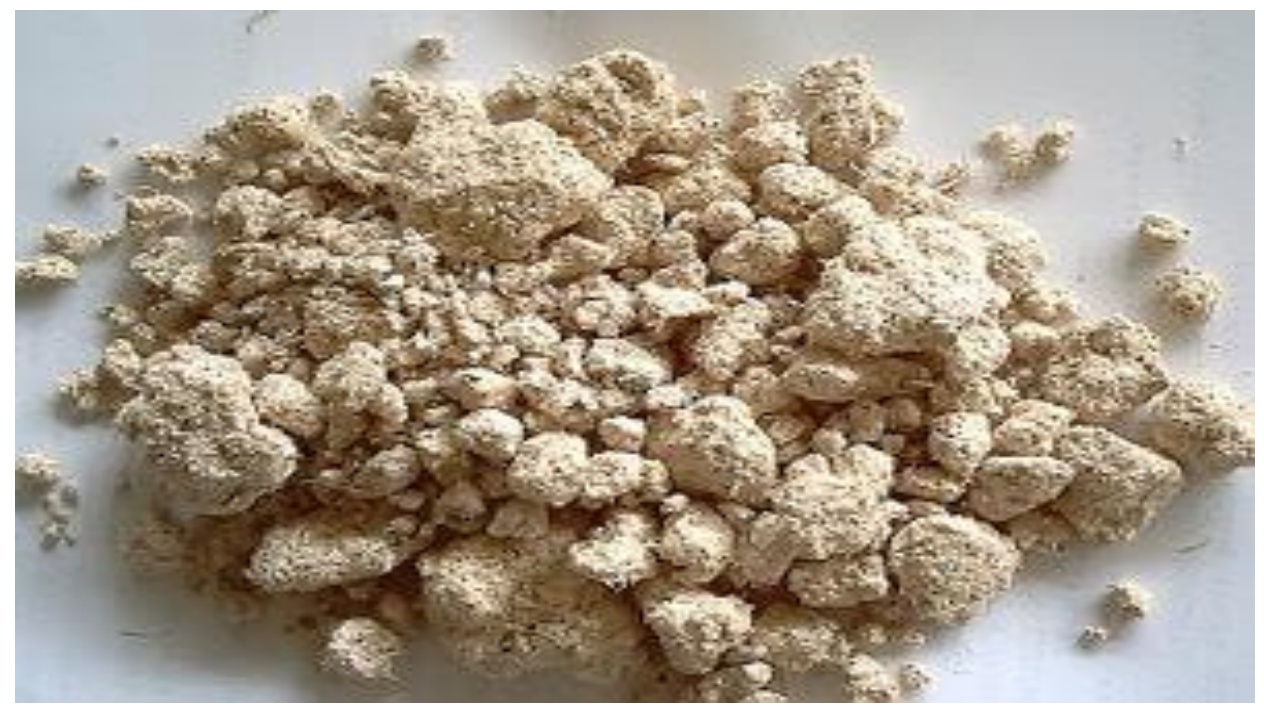

Gambar 1. Onggok Singkong 
Tabel 1. Komposisi Kimia Onggok

\begin{tabular}{ll}
\hline \hline Komponen & Kisaran $(\%)$ \\
\hline \hline Pati & $60-80$ \\
Serat kasar & $8-22$ \\
Protein & $0,80-6,42$ \\
Lemak & $0,25-0,26$ \\
Air & $14-20$ \\
\hline
\end{tabular}

\section{TUJUAN}

Tulisan ini bertujuan menggali potensi pemanfaatan onggok sebagai medium padatan untuk menghasilkan produk bernilai ekonomik tinggi. Konsep demikian disebut sebagai waste exchange atau waste to product. Dengan konsep tersebut terdapat peluang membangun industri proses yang berkelanjutan selaras dengan paradigma sustainable consumption and production.

\section{METODE}

Dalam menyusun tulisan ini digunakan metode penelusuran informasi sekunder yang diperoleh dari jurnal (nasional dan internasional), laporan teknis, textbook, buku pegangan (handbook) serta sejumlah sumber lainnya yang dapat diperoleh dari laman internet.

\section{POLYUNSATURATED FATTY ACID}

\section{Polyunsaturated} fatty Polyunsaturated fatty acid (PUFA) adalah suatu asam lemak yang dalam molekulnya terdapat lebih dari satu ikatan ganda (multiple bond). Asam lemak yang termasuk ke dalam kelompok PUFA adalah essential fatty acid serta senyawaan pembentuk ciri atau khas suatu drying oil. Berdasarkan bangun kimia PUFA dapat dikelompokkan menjadi tiga yaitu: (i) poliena tersisip metilena, (ii) asam lemak terkonjugasi dan (iii) PUFA jenis lainnya. Yang tergolong ke dalam poliena tersisip metilena adalah omega-3, omega- 6 serta omega-9. Dua asam lemak pertama merupakan essential fatty acid. Asam lemak omega-9 bukan merupakan essential fatty acid dikarenakan manusia dan hewan mampu menyisipkan ikatan takjenuh pada atom karbon di posisi nomor 9 melalui proses periptaan biologik (biological synthesis atau biosynthesis). Perbedaan ketiga jenis asam lemak beserta sumbernya disajikan pada Tabel 2 (Geeshani 2016). Beberapa contoh PUFA poliena tersisip metilena, asam lemak terkonjugasi serta PUFA jenis lainnya disajikan pada Tabel 3 sampai 5 (Wikipedia 2018). Sedangkan bangun molekul contoh dari asam lemak tak jenuh omega3, omega-6 serta omega-9 disajikan pada Gambar 3.

Beberapa PUFA yang dikenal juga dengan sebutan asam lemak tak jenuh jamak tidak dapat diripta (synthesized) oleh sistem tubuh manusia. Oleh sebab itu PUFA seperti omega-3 dan omega-6 harus didapat melalui asupan makanan. Kedua asan lemak tersebut diketahui bermanfaat dalam proses tumbuh kembang anak, peningkatan kecerdasan, serta metabolisme. Sekitar 60\% nutrisi untuk proses perkembangan otak berupa lemak (Putri 2016). Dibandingkan dengan asam lemak ikatan jenuh ataupun asam lemak dengan konfigurasi ikatan isomer trans pada umumnya maka PUFA lebih aman untuk dikonsumsi karena menekan perningkatan Low 
Density Lipoprotein (LDL) dalam tubuh manusia, yakni kolesterol yang memicu timbulnya penyakit jantung dan stroke.

Dengan meningkatnya populasi manusia maka kebutuhan nutrisi lemak dan minyak juga meningkat (Sumanti et al. 20005).
Sumberdaya alam yang terbatas menyebabkan inovasi dalam perekayasaan produksi PUFA perlu diupayakan, misal dengan memanfaatkan limbah sebagai sumberdaya. Untuk tujuan tersebut onggok tapioka merupakan limbah dengan potensi pemanfaatan dalam periptaan PUFA

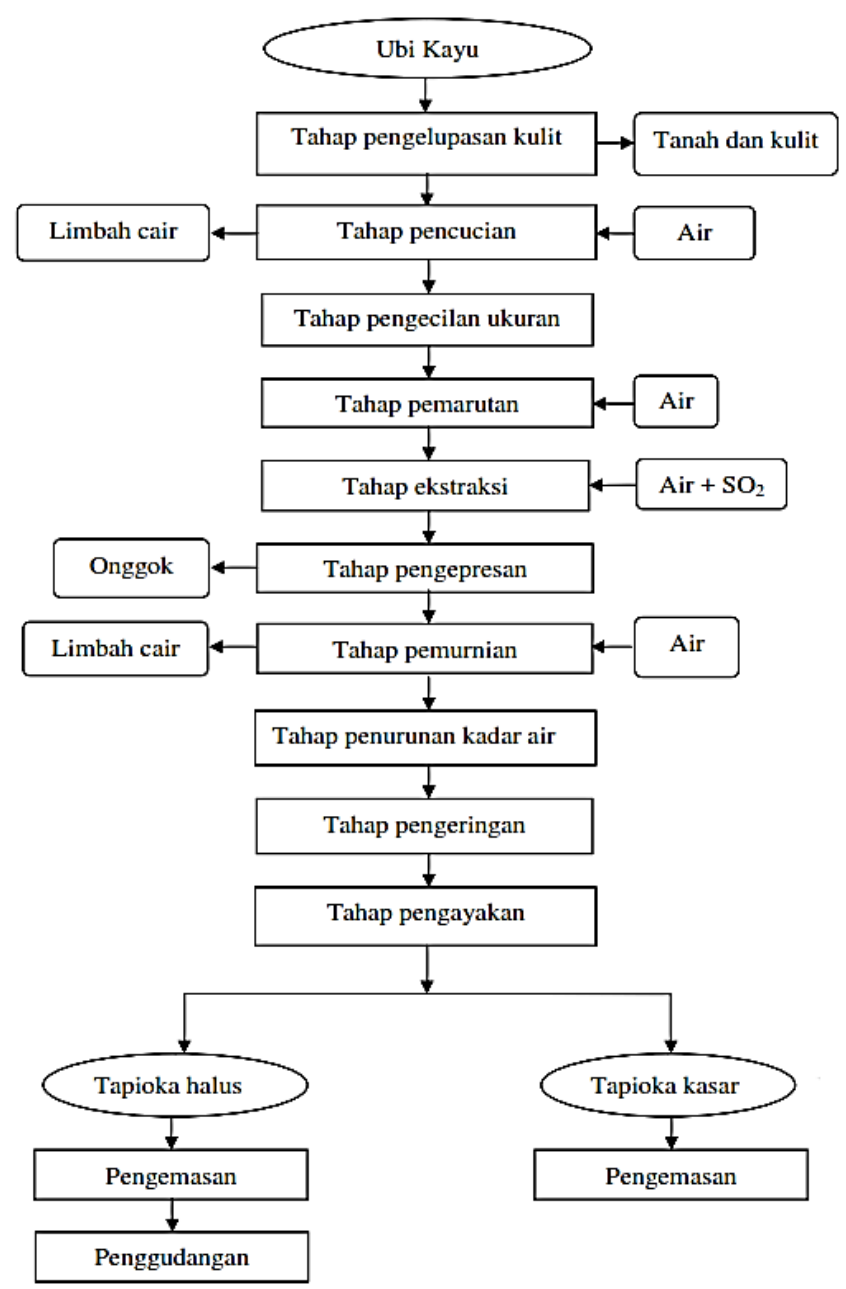

Gambar 2. Diagram proses pembuatan tapioka 
Tabel 2 Perbedaan dan Sumber Omega-3, Omega-6 dan Omega-9

\begin{tabular}{|c|c|c|}
\hline Omega-3 & Omega-6 & Omega-9 \\
\hline $\begin{array}{l}\text { Ikatan tak jenuh dijumpai } \\
\text { pertama kali pada posisi } \\
\text { atom karbon ke-3 dihitung } \\
\text { dari ujung metil rantai } \\
\text { karbon }\end{array}$ & $\begin{array}{l}\text { Ikatan tak jenuh dijumpai } \\
\text { pertama kali pada posisi } \\
\text { atom karbon ke-6 } \\
\text { dihitung dari ujung metil } \\
\text { rantai karbon }\end{array}$ & $\begin{array}{l}\text { Ikatan tak jenuh dijumpai } \\
\text { pertama kali pada posisi } \\
\text { atom karbon ke93 } \\
\text { dihitung dari ujung metil } \\
\text { rantai karbon }\end{array}$ \\
\hline $\begin{array}{l}\text { Merupakan essential fatty } \\
\text { acid }\end{array}$ & $\begin{array}{l}\text { Merupakan essential fatty } \\
\text { acid }\end{array}$ & $\begin{array}{l}\text { Bukan essential fatty } \\
\text { acid }\end{array}$ \\
\hline $\begin{array}{l}\text { Sumber: buah zaitun, } \\
\text { kacang makadamia, } \\
\text { bunga kanola, rapeseed, } \\
\text { wallflower dan mustard } \\
\text { seed }\end{array}$ & $\begin{array}{l}\text { Sumber: unggas, telur, } \\
\text { kacang-kacangan, sereal, } \\
\text { gandum, minyak nabati } \\
\text { serta fitoplankton }\end{array}$ & $\begin{array}{l}\text { Sumber: kenari, biji- } \\
\text { bijian yang dapat } \\
\text { dimakan, flaxseed oil, } \\
\text { Echium oil, minyak rami, } \\
\text { minyak ikan dan alga } \\
\text { laut }\end{array}$ \\
\hline
\end{tabular}

Tabel 3 PUFA Poliena Tersisip Metilena

\begin{tabular}{|c|c|c|}
\hline Nama Umum & Nama Lipida & Nama Kimia \\
\hline \multicolumn{3}{|l|}{ Omega-3 } \\
\hline Asam heksadekatrienoat (HTA) & $16: 3(n-3)$ & $\begin{array}{l}\text { Asam cis } 7,10,13- \\
\text { heksadekatrienoat }\end{array}$ \\
\hline Asam alfa-linolenat (ALA) & $18: 3(n-3)$ & $\begin{array}{l}\text { Asam cis- } 9,12,15- \\
\text { oktadekatrienoat }\end{array}$ \\
\hline Asam stearidonat (SDA) & $18: 4(n-3)$ & $\begin{array}{l}\text { Asam cis- } 6,9,12,15,- \\
\text { oktadekatetraenoat }\end{array}$ \\
\hline Asam eikosatrienoat (ETE) & $20: 3(n-3)$ & $\begin{array}{l}\text { Asam cis- } 11,14,17- \\
\text { eikosatrienoat }\end{array}$ \\
\hline Asam eikosatetraenoat (ETA) & $20: 4(n-3)$ & $\begin{array}{l}\text { Asam cis- } 8,11,14,17- \\
\text { eikosatetraenoat }\end{array}$ \\
\hline $\begin{array}{l}\text { Asam eikosapentaenoat (EPA, asam } \\
\text { timnodonat) }\end{array}$ & $20: 5(n-3)$ & $\begin{array}{l}\text { Asam cis- } \\
5,8,11,14,17- \\
\text { eikosapentaenoat }\end{array}$ \\
\hline Asam heneikosapentaenoat (HPA) & $21: 5(n-3)$ & $\begin{array}{l}\text { Asam cis- } \\
6,9,12,15,18 \text { - } \\
\text { heneikosapentaenoat }\end{array}$ \\
\hline $\begin{array}{l}\text { Asam dokosapentaenoat (DPA, } \\
\text { Clupanodonic acid) }\end{array}$ & $22: 5(n-3)$ & $\begin{array}{l}\text { Asam cis- } \\
7,10,13,16,19- \\
\text { dokosapentaenoat }\end{array}$ \\
\hline $\begin{array}{l}\text { Asam dokosaheksaenoat (DHA, asam } \\
\text { servonat) }\end{array}$ & $22: 6(n-3)$ & $\begin{array}{l}\text { Asam cis- } \\
4,7,10,13,16,19- \\
\text { dokosaheksaenoat }\end{array}$ \\
\hline Asam tetrakosapentaenoat & $24: 5(n-3)$ & $\begin{array}{l}\text { Asam cis- } \\
9,12,15,18,21 \text { - } \\
\text { tetrakosapentaenoat }\end{array}$ \\
\hline \multicolumn{3}{|l|}{ Omega-6 } \\
\hline Asam linoleat & $18: 2(n-6)$ & $\begin{array}{l}\text { Asam cis-9,12- } \\
\text { oktadekadienoat }\end{array}$ \\
\hline Asam gamma-linolenat (GLA) & $18: 3(n-6)$ & $\begin{array}{l}\text { Asam cis- } 6,9,12- \\
\text { oktadekatrienoat }\end{array}$ \\
\hline
\end{tabular}


Asam eikosadienoat

Asam dihomo-gamma-linolenat (DGLA)

Asam Arakidonat (AA)

Asam dokosadienoat

Asam adrenat

Asam dokosapentaenoat (asam osbond)

Asam tetrakosatetraenoat

Asam tetrakosapentaenoat

Omega-9
Asam oleat*
Asam eikosanoat*
Asam mead
Asam erukat*
Asam nervonat* $^{*}$

$20: 2(n-6)$

$20: 3(n-6)$

$20: 4(n-6)$

$22: 2(n-6)$

$22: 4(n-6)$

$22: 5(n-6)$

$24: 4(n-6)$

$24: 5(n-6)$

$18: 1(n-9)$

$20: 1(n-9)$

$20: 3(n-9)$

$22: 1(n-9)$

$24: 1(n-9)$
Asam cis-11,14eikosadienoat Asam cis-8,11,14eikosatrienoat Asam cis-5,8,11,14eikosatetraenoat Asam cis-13,16dokosadienoat Asam cis-7,10,13,16dokosatetraenoat Asam cis4,7,10,13,16dokosapentaenoat Asam cis-9,12,15,18tetrakosatetraenoat Asam cis$6,9,12,15,18$ tetrakosapentaenoat

*Merupakan monotakjenuh
Asam cis-9oktadekenoat Asam cis-11eikosanoat Asam cis-5,8,11eikosatrienoat dokosenoat Asam cis-15tetrakosenoat Asam cis-13-

Tabel 4 PUFA asam lemak terkonjugasi

\section{\begin{tabular}{c} 
Nama Umum \\
\hline Asam linoleat terkonjugasi*
\end{tabular}}

Nama Lipida

Nama Kimia

Asam 9Z,11E-oktadeka-9,11dienoat

18:2 (n-6) Asam 10E,12Z-oktadeka-10,12dienoat

18:3 (n-6) Asam 8E,10E,12Zoktadekatrienoat 18:3 (n-6) Asam 8E, 10E,12Eoktadekatrienoat

18:3 (n-6) Asam 8Z,10E,12Zoktadekatrienoat

18:3 (n-5) Asam 9Z,11E,13E-oktadeka9,11,13-trienoat 


\begin{tabular}{|c|c|c|}
\hline Nama Umum & $\begin{array}{l}\text { Nama } \\
\text { Lipida }\end{array}$ & Nama Kimia \\
\hline Asam $\beta$ - eleostearat & $18: 3(n-5)$ & $\begin{array}{l}\text { Asam 9E,11E,13E-oktadeka - } \\
9,11,13 \text {-trienoat }\end{array}$ \\
\hline Asam katalpat & $18: 3(n-5)$ & $\begin{array}{l}\text { Asam 9Z,11Z,13E-oktadeka - } \\
9,11,13 \text {-trienoat }\end{array}$ \\
\hline Asam punikat & $18: 3(n-5)$ & $\begin{array}{l}\text { Asam 9Z,11E,13Z-oktadeka- } \\
9,11,13 \text {-trienoat }\end{array}$ \\
\hline \multicolumn{3}{|l|}{ Lainnya } \\
\hline Asam rumelenat & $18: 3(n-3)$ & $\begin{array}{l}\text { Asam 9E,11Z,15E-oktadeka- } \\
9,11,15 \text {-trienoat }\end{array}$ \\
\hline Asam a-parinarat & $18: 4(n-3)$ & $\begin{array}{l}\text { Asam 9E,11Z,13Z,15E-oktadeka- } \\
9,11,13,15 \text {-tetraenoat }\end{array}$ \\
\hline Asam $\beta$-parinarat & $18: 4(n-3)$ & $\begin{array}{l}\text { Asam trans-oktadeka- } 9,11,13,15- \\
\text { tretraenoat }\end{array}$ \\
\hline Asam boseopentaenoat & $20: 5(n-6)$ & $\begin{array}{l}\text { Asam } 5 Z, 8 Z, 10 E, 12 E, 14 Z- \\
\text { eikosanoat }\end{array}$ \\
\hline \multicolumn{3}{|c|}{$\begin{array}{l}{ }^{\star} \text { Merupakan dua ikatan ganda terkonjugasi }{ }^{* *} \text { Merupakan tiga ikatan ganda } \\
\text { terkonjugasi }\end{array}$} \\
\hline \multicolumn{3}{|c|}{ Tabel 5 Polyunsaturated fatty acid lainnya } \\
\hline Nama Umum & Nama Lipida & Nama Kimia \\
\hline Asam pinolenat & $18: 3(n-6)$ & $\begin{array}{l}\text { Asam }(5 Z, 9 Z, 12 Z) \text {-oktadeka- } \\
5,9,12 \text {-trienoat }\end{array}$ \\
\hline Asam podokarpat & $20: 3(n-6)$ & $\begin{array}{l}\text { Asam (5Z,11Z,14Z)-eikosa- } \\
5,11,14 \text {-trienoat }\end{array}$ \\
\hline
\end{tabular}

Methyl Carboxyl

Estearic acid $\mathrm{CH}_{3}$

(C18:0)

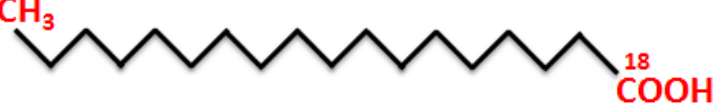

Oleic acid

(C18:2, $\omega-9)$

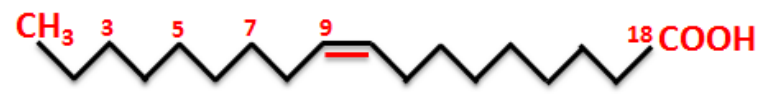

Linoleic acid $\mathrm{CH}_{3}$

(C18:2, $\omega-6)$

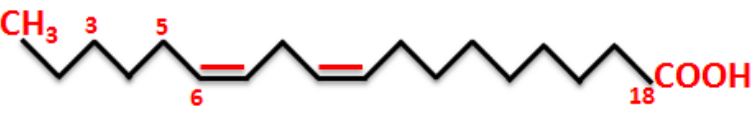

alpha-linolenic $\mathrm{CH}_{3}$ acid

$(\mathrm{C} 18: 3, \omega-3)$

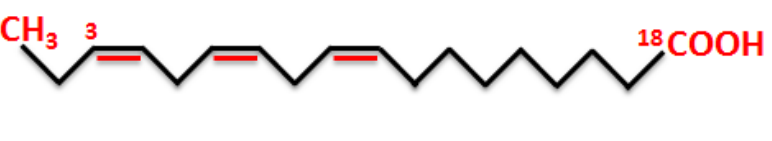

Gambar 3. Bangun Molekul Contoh Omega-3, Omega-6 dan Omega-9 


\section{TEKNIK PEMISAHAN PUFA}

Terdapat sejumlah teknik
yang dapat diterapkan dalam
proses produksi pekatan
(concentrate) PUFA meliputi cara
fisika, kimia serta biologi. Contohnya adalah penyulingan (destillation), pengkristalan suhu rendah, penyarian (extraction), zalir (fluid) superkritik, kromatografik, pengkompleksan urea serta pemisahan enzimatik (Patil 2014, Kapoor \& Patil 2011, RobioRodriguez et al. 2010).

Pada metode penyulingan prinsip yang digunakan adalah perbedaan suhu didih antar asam lemak. Metode demikian hanya sangkil (efficient) jika minimum perbedaan suhu didih di antara asam lemak setidaknya $10{ }^{\circ} \mathrm{C}$. Biasanya penyulingan campuran asam lemak dilakukan pada tekanan cukup rendah (sekitar 2 $\mathrm{mmHg}$ ) guna menghindari perombakan struktur molekul asam lemak yang akan dipisahkan. Pada tekanan rendah maka suhu didih asam lemak yang akan dipisahkan juga berkurang sehingga proses pemisahan dapat berlangsung lebih cepat.

Teknik pengkristalan pada suhu rendah dikembangkan untuk pemisahan campuran asam lemak atau ester asam lemak yang dapat larut dalam pelarut organik (biasanya metanol atau aseton) pada suhu ruang namun menjadi tidak larut jika suhu diturunkan menuju ke $0{ }^{\circ} \mathrm{C}$. Titik lebur atau titik leleh asam lemah berubah secara nyata dengan tingkat ketidakjenuhan sehingga pemisahan menjadi dimungkinkan. Terkadang pemisahan campuran asam lemak dengan teknik ini dapat dilakukan secara langsung tanpa menggunakan pelarut organik. Asam lemak jenuh atau asam lemak dengan derajat ketakjenuhan rendah (misalnya adalah monounsaturated fatty acids atau MUFA) akan mengkristal lebih cepat dibandingkan PUFA sehingga dengan melakukan penyaringan bisa didapatkan pekatan PUFA.

Penyarian menggunakan zalir superkritik dilakukan pada suhu kritik atau tekanan kritik zalir tersebut. Perubahan kecil baik suhu maupun tekanan dalam keadaan kritik dapat menghasilkan perubahan sifat fisik yang drastis seperti kekentalan (viscosity) atau kebauran (diffusivity). Zalir yang sering digunakan untuk teknik ini adalah karbon dioksida $\left(\mathrm{CO}_{2}\right)$ walaupun air $\left(\mathrm{H}_{2} \mathrm{O}\right)$ memungkinkan pula untuk digunakan. Suhu kritik dan tekanan kritik untuk karbon dioksida adalah $31,1{ }^{\circ} \mathrm{C}$ dan 72,9 atm. Sedangkan untuk air adalah $374{ }^{\circ} \mathrm{C}$ dan 218 atm. Karena kondisi kritik untuk karbon dioksida lebih mudah dan menguntungkan untuk dicapai maka tidak heran apabila karbon dioksida lebih banyak digunakan sebagai pelarut dalam proses penyarian pada kondisi kritik. Gambar 4 menyajikan diagram kritik untuk karbon dioksida dan air (Annenberg Foundation 2017).

Asam lemak bebas (free fatty acids) juga dapat dipisahkan berdasarkan baku tindak (interaction) molekul tersebut dengan fasa diam (stationary phase) dan fasa gerak (mobile phase) dalam kolom kromatografik. Perbedaan jumlah atom karbon maupun derajat ketidakjenuhan sangat berpengaruh terhadap tingkat kemudahan pemisahan campuran asam lemak dalam kolom kromatografik. Kromatografi Cair 
Kinerja Tinggi (High Performance Liquid

preparative HPLC serta kromatografi resin perak telah digunakan dalam mendapatkan pekatan PUFA. Juga teknik kromatografi lapis tipis (thin layer chromatography) juga pernah diterapkan untuk mendapatkan PUFA sebagai metil ester (Patil 2014).

Pemisahan asam lemak melalui mekanisme pembentukan kompleks dengan urea menggunakan fenomena pembentukan molekul sepit (chelate). Urea merupakan padatan kristal dengan bangun kristal berbentuk tetragonal. Namun dengan adanya asam lemak struktur kristal urea berubah menjadi heksagonal karena pembentukan sepit. Hanya molekul asam lemak linear yang dapat membentuk sepit dengan urea. Dengan cara demikian PUFA dapat dipisahkan dari MUFA. Pembentukan kompleks antara urea dengan asam lemak dipandang yang paling sederhana dalam proses pemisahan MUFA dan PUFA (Hamam \& Sahidi 2008) walaupun kombinasi berbagai metode juga dimungkinkan untuk mendapatkan pekatan PUFA (Patil \& Nag 2011). Pada Gambar 5 disajikan struktur kristal urea dalam bentuk tetragonal dan heksagonal dalam bentuk tiga matra (Guo at al. 2017) dan dua matra (Shahidi \& Wanasundara 1998.

Pemekatan PUFA dengan metode hidrolisis enzimatik atau reaksi esterifikasi menggunakan berbagai lipase. Teknik pemisahan tersebut berdasarkan tekukan (bending) rantai asam lemak karena adanya ikatan ganda cis-olefinik. Akibat dari tekukan rantai asam lemak tersebut gugus metil ujung menjadi berdekatan dengan ikatan ester sehingga menimbulkan hambatan sterik (steric hindrance) untuk menghidrolisisnya. Tekukan yang kuat untuk EPA dan DHA dikarenakan adanya lima dan enam ikatan ganda sehingga hambatan sterik yang ditimbulkan menghalangi lipase untuk dapat mencapai ikatan ester antara asam lemak dengan gliserol. Sebaliknya asam lemak jenuh dan MUFA tidak membentuk hambatan sterik seperti itu sehingga keduanya mudah untuk dihidrolisis oleh lipase. Dalam sejumlah reaksi esterifikasi berbagai lipase yang berbeda menunjukkan kinetika yang berbeda dengan beragam asam lemak. Perbedaan kinetika yang ditunjukkan tersebut dapat pula diterapkan untuk memisahkan EPA dengan DHA menggunakan enzim lipase. 


\section{$\mathrm{CO}_{2}$ Phase Diagram}
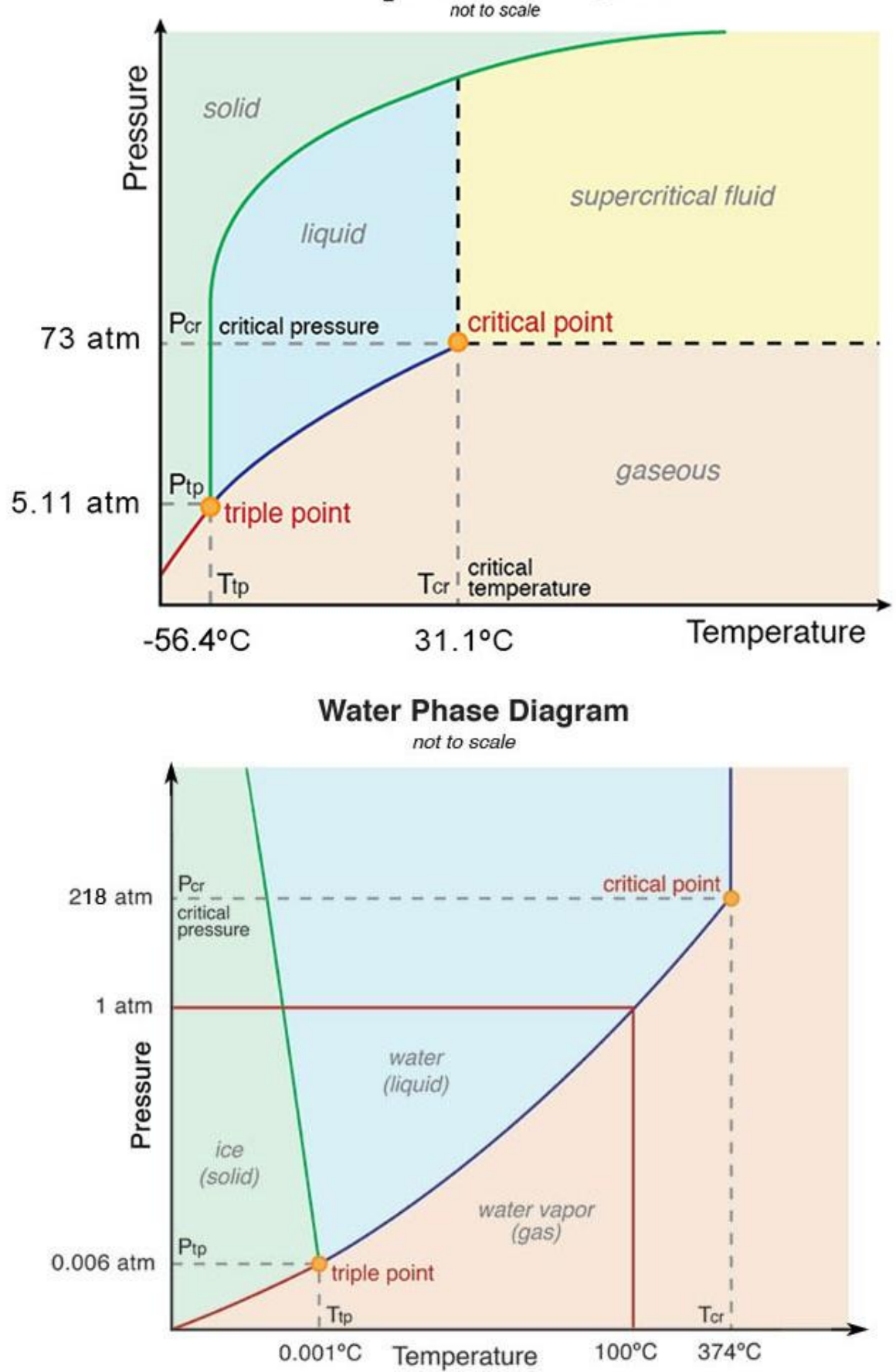

Gambar 4. Diagram Kritik untuk Karbon Dioksida (atas) dan Air (bawah) 


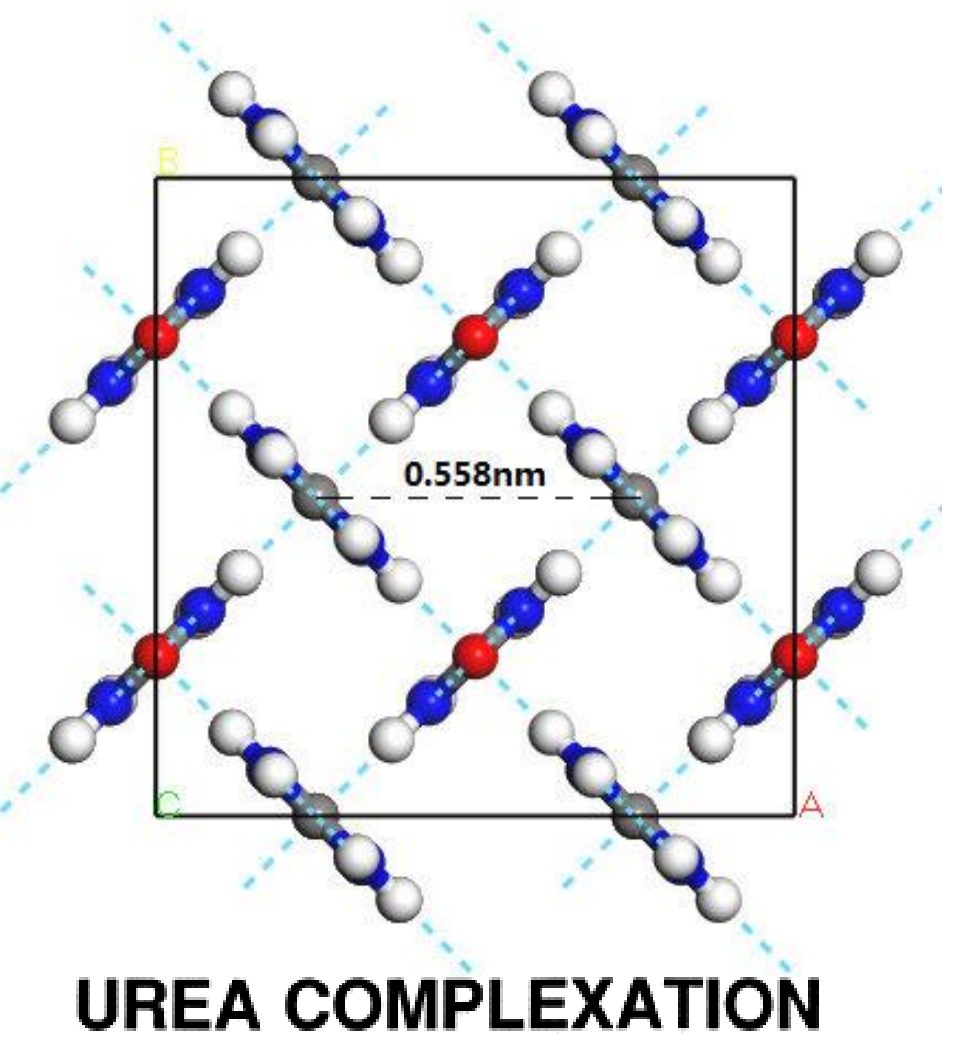

UREA: $\mathrm{CO}\left(\mathrm{NH}_{2}\right)_{2}$

(Tetragonal)

UREA \& STRAIGHT

CHAIN MOLECULES

(Hexagonal)

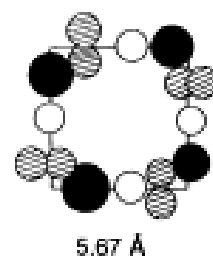

Free fatty acid mixture

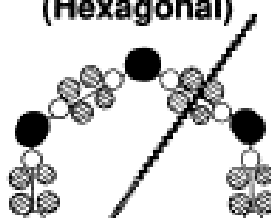

+ PUFA

(NUCF)

Saturated/monounsaturated fatty acid(s)

$\mathrm{O}_{\mathrm{Nen}}$
$\mathrm{NH}_{2}$

Gambar 5. Kristal Tiga Matra dan Dua Matra Urea 


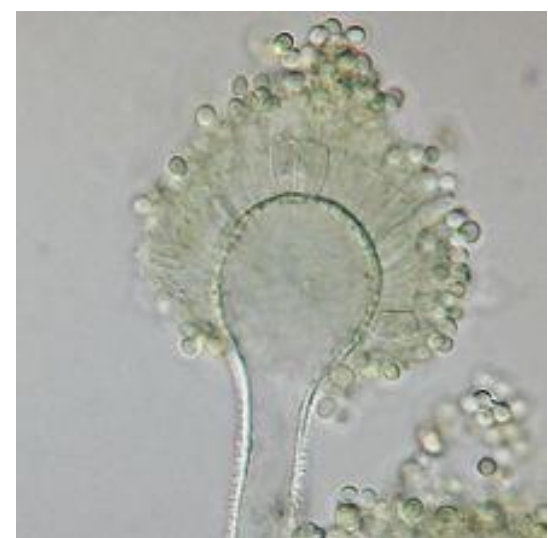

A. flavus

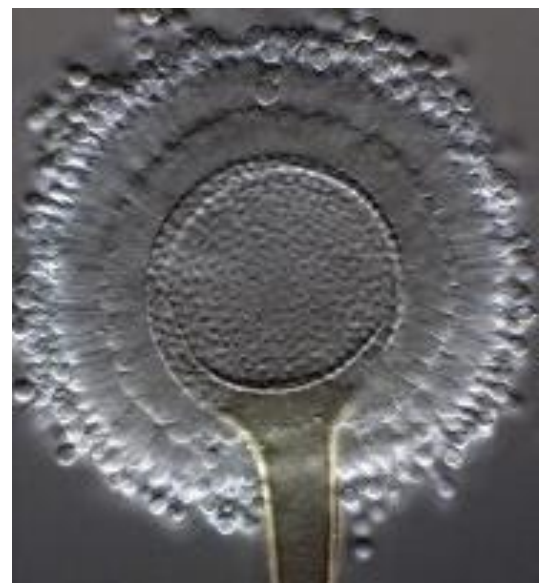

A. ochraceus

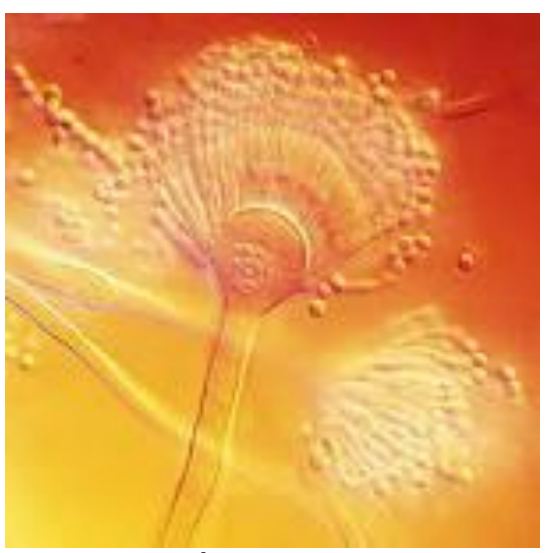

A. terreus

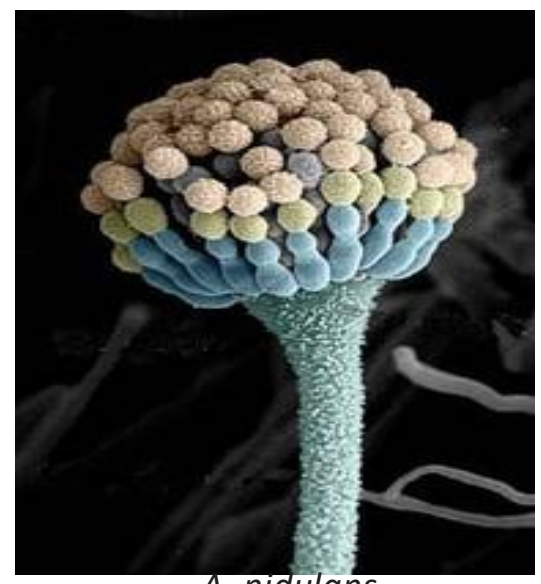

A. nidulans

Gambar 6. Penampakan visual berbagai spesies kapang Aspergillus

\section{PERIPTAAN PUFA}

Periptaan

(synthesis)

polyunsaturated fatty acids dapat dilakukan secara kimia maupun biologik. Metode biologik umumnya dilakukan dengan menggunakan kapang (fungi). Kapang Aspergillus merupakan agensia biologik yang telah banyak diterapkan dalam proses pembuatan kecap, tauco dan miso (Sumanti et al. 2005). Misalnya Aspergillus flavus mampu menghasilkan lemak sebanyak $28 \%$
A. nidulans $51 \%$,

ochraceus $48 \%$ dan A. terreus $57 \%$. Dari berbagai spesies kapang tersebut diketahui bahwa Aspergillus terreus mampu menghasilkan asam lemak tertinggi serta memberikan komposisi asam lemak tidak jenuh yang lebih tinggi pula (Sumanti dkk. 2005). Jenis asam lemak yang dihasilkan oleh $A$. terreus menyerupai asam lemak yang terdapat dalam minyak kelapa sawit yaitu linolenat dan linoleat. Pada Gambar 6 disajikan berbagai macam kenampakan visual dari beragam spesies Aspergillus (The 
Aspergillus Website 2018).

Kapang Aspergillus dikenal pula memiliki kemampuan mendegradasi bahan organik termasuk limbah sehingga berpotensi untuk diterapkan dalam mengolah limbah onggok, ampas tahu, molase serta dedak padi. Limbah tersebut oleh kapang Aspergillus dapat dijadikan sebagai substrat sumber karbon untuk proses pertumbuhan dan perkembangan kapang tersebut. Untuk dapat tumbuh kembang dengan baik kapang memerlukan sumber karbon, nitrogen, vitamin dan mineral. Sejumlah faktor yang berpengaruh terhadap proses produksi minyak sel tunggal oleh kapang adalah suhu, keasaman
$(\mathrm{pH})$ medium tumbuh, waktu inkubasi, aerasi, sumber karbon, nitrogen, vitamin dan mineral (Sumanti dkk. 2005). Nisbah (ratio) karbon terhadap nitrogen juga mengendalikan kesangkilan (efficiency) proses biologik. Proses biologik yang mengandalkan jasad renik seringkali memiliki pendekatan nilai nisbah karbon : nitrogen : fosfor $=100: 10: 1$ (terkadang nisbah $\mathrm{C}: \mathrm{N}: \mathrm{P}=100$ : $10: 0,5)$. Nisbah karbon terhadap nitrogen yang optimal harus menunjukkan kemampuan produksi biomassa maksimum untuk setiap satuan massa substrat, menekan pembentukan produk yang tidak diinginkan, serta memberikan laju kinetik produksi tercepat dengan hasil atau produk yang baik.

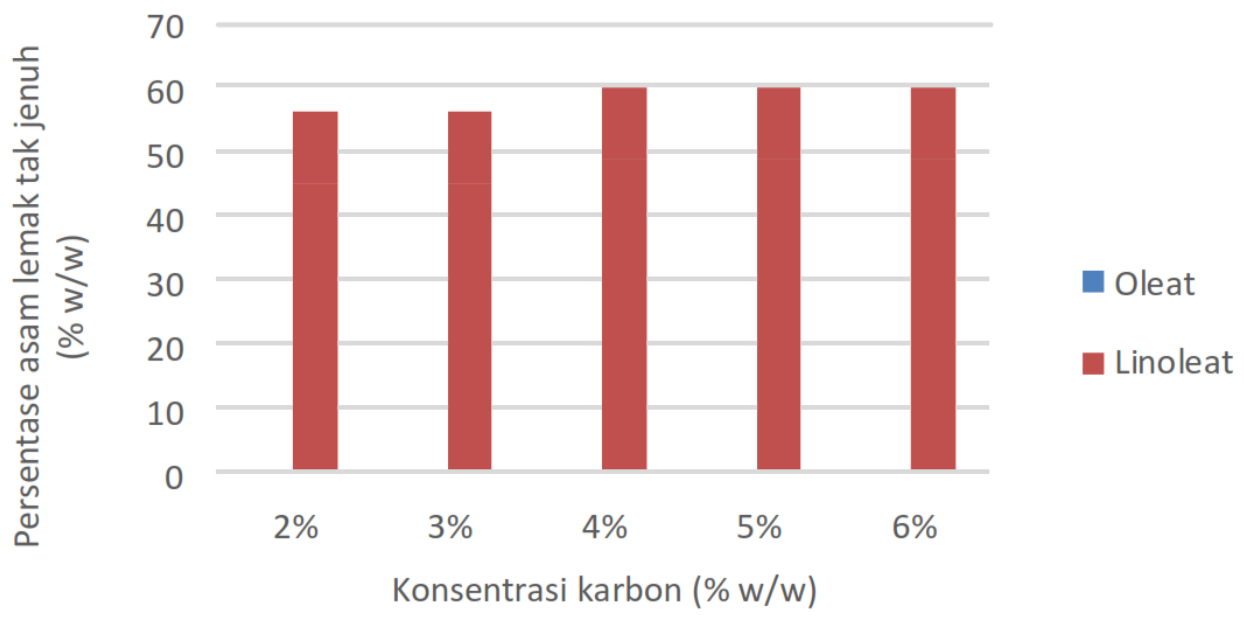

Gambar 7. Prosentase PUFA pada Berbagai Ragam Aras Karbon 


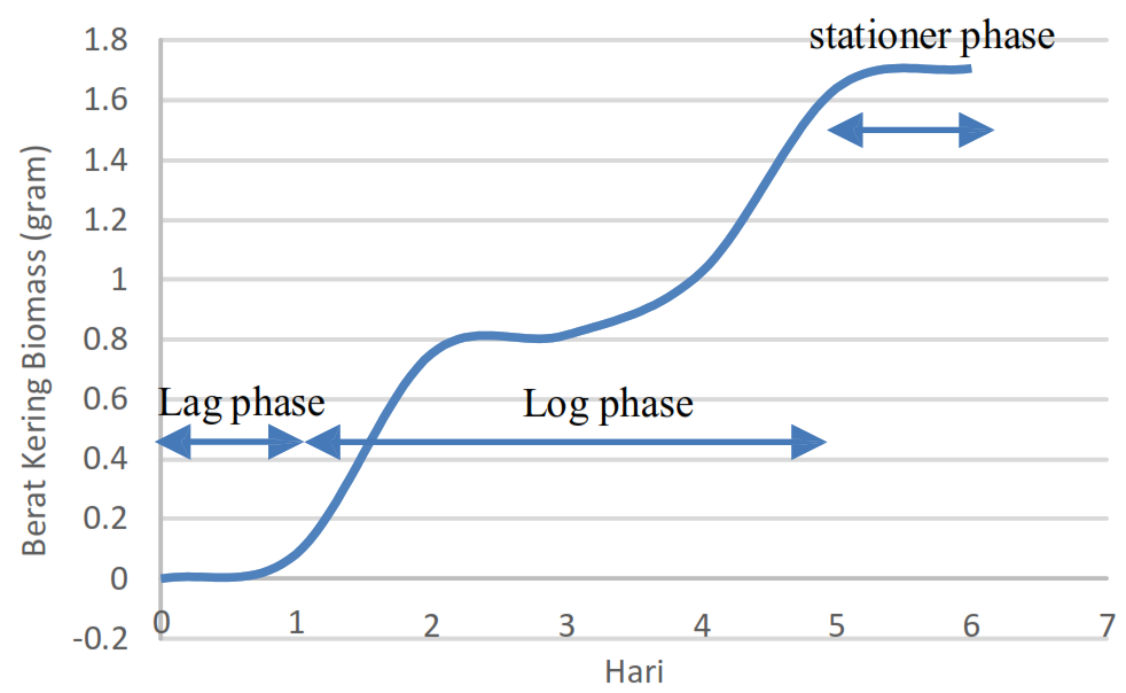

Gambar 8. Pola Lung (curve) Pertumbuhan Biomassa Kapang A. oryzae

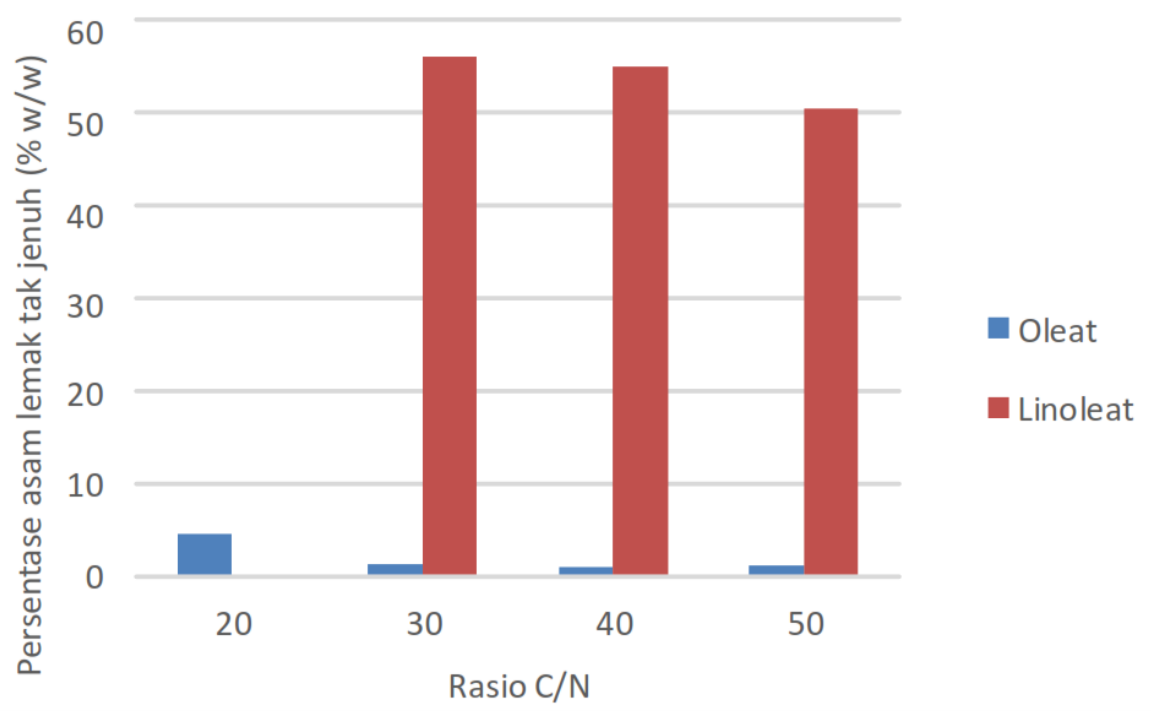

Gambar 9. Prosentase PUFA pada Peragaman Nisbah C/N

Penelitian yang dilakukan oleh Putri $d k k$ (2016) menunjukkan bahwa pemanfaatan onggok sebagai medium fermentasi padat dalam produksi PUFA memberikan peningkatan jumlah PUFA seiring dengan peningkatan aras karbon dalam kisaran $2-6 \%$ (w/w). Pada aras karbon 6\% (w/w) PUFA yang dihasilkan adalah 60,8\%. Hasilhasil pengukurannya ditunjukkan pada Gambar 7. Pemanenan kapang untuk mendapatkan lipida harus dilakukan pada masa 
pertumbuhan stationary, yakni fase di mana tidak lagi terjadi penambahan bobot kering bimassa kapang seiring dengan waktu. Oleh sebab itu fase stationary merupakan saat di mana bobot lipida yang terbentuk adalah maksimum. Pemanenan yang terlalu lama dari titik awal fase stationary akan menyebabkan penuruan bobot lipida yang telah terbentuk. Hal ini disebabkan oleh Berbeda dengan respon yang ditunjukkan oleh pengaruh peragaman aras karbon, peragaman nisbah karbon terhadap nitrogen justru memberikan respon yang sebaliknya. Dengan meningkatnya nisbah $\mathrm{C} / \mathrm{N}$ dalam kisaran 20 - 50 PUFA yang dihasilkan semakin berkurang. Hal ini dapat dilihat pada Gambar 9 (Putri et al. 2016). Teknik yang digunakan untuk memekatkan PUFA adalah penyarian (extraction) dengan menggunakan pelarut etanol pada suhu $45^{\circ} \mathrm{C}$ selama 3 jam. Perbandingan volume $(\mathrm{mL})$ pelarut etanol terhadap bobot biomassa (mg) kapang adalah 15:1. Sebelum penyarian dilakukan dinding sel kapang harus dipecah dengan proses sonifikasi (yakni perlakukan pemberian getaran melalui pendedahan (exposure) gelombang elektronik ultrasonik) agar lipida yang terdapat dalam sel dapat larut dalam etanol. Prinsip yang digunakan dalam semua proses penyarian adalah like dissolve like yakni bahan dengan kepolaran yang serupa atau berdekatan cenderung untuk bergabung. Dalam hal ini kepolaran etanol menyerupai kepolaran asam lemak sehingga lipida dapat dikeluarkan dari sel kapang. Kepolaran ini dapat diprediksikan dari struktur molekul etanol dan kurangnya zat hara pada fase stationary sehingga lipida yang terbentuk digunakan kembali sebagai sumber karbon (AbuElreesh \& Abd-El-Haleem 2013). Fase stationary pertumbuhan untuk kapang Aspergillus oryzae biasanya terjadi pada kisaran hari ke 3 - 5 dari masa pertumbuhan sebagaimana diperlihatkan pada Gambar 8 (Putri et al. 2016).

asam lemak. Sifat polar etanol disumbang oleh gugus hidroksil ($\mathrm{OH}$ ) sedangkan kepolaran asam lemak disumbang selain gugus hidroksil juga oleh gugus karbonil($\mathrm{C}=\mathrm{O}$ ). Baik etanol maupun asam karboksilat sama-sama memiliki kemampuan membentuk jembatan hidrogen.

\section{POTENSI REKAYASA PROSES}

Pemanfaatan onggok sebagai medium fermentasi padat pada dasarnya adalah pemanfaatan sumber karbon yang terdapat dalam onggok melalui proses enzimatik. Teknik demikian mengurangi risiko perancuan (contamination) oleh bakteri dikarenakan tidak adanya air-bebas serta rendahnya $\mathrm{pH}$. Intraselular enzim dihasilkan oleh kapang Aspergillus oryzae untuk mencerna karbon yang terdapat dalam onggok. Karena enzim adalah katalis biologik maka dimungkinkan untuk merekayasa kinetika enzimatik dengan mengatur aras $\mathrm{pH}$ dan suhu operasi. Biasanya kinetika reaksi akan meningkatkan dua kali lipat bila suhu reaksi meningkat setiap $10{ }^{\circ} \mathrm{C}$. Namun karena enzim adalah protein maka terdapat suhu di mana proses denaturasi protein bisa terjadi. Hal 
ini harus dihindari karena akan mendeaktivasi kemampuan enzim dalam mencerna substrat. Demikian pula dengan $\mathrm{pH}$ medium reaksi yang mana proses enzimatik memiliki rentang $\mathrm{pH}$ yang khas. Faktor lain yang tidak kalah penting adalah waktu inkubasi (Pinasthika 2018) dan laju agitasi (Arcanggi 2018) sebagaimana yang diperlihatkan pada Gambar 10 dan 11. Dengan mengatur kondisi operasional ini maka produksi PUFA dapat dioptimalkan.

\section{SIMPULAN}

Onggok merupakan sisa produksi tapioka yang masih mengandung bahan organik sebagai sumber karbon bagi pertumbuhan kapang Aspergillus oryzae. Dengan memanfaatkan onggok sebagai media fermentasi padat dalam produksi polyunsaturated fatty acids (PUFA) maka potensi pengurangan biaya operasional dalam produksi PUFA dimungkinkan. Hal ini akan meningkatkan keunggulan kinerja operasi produksi tidak hanya dari sudut pandang daya saing bisnis namun juga lingkungan. Selain itu dengan memanfaatkan limbah sebagai bahan baku proses maka penerapan konsep waste to product atau waste exchange menjadi terwujud. Dampaknya adalah potensi penurunan beban lingkungan yang ditimbulkan oleh limbah onggok. Pada gilirannya Sustainanle Consumption and Production akan mendekati kenyataan.

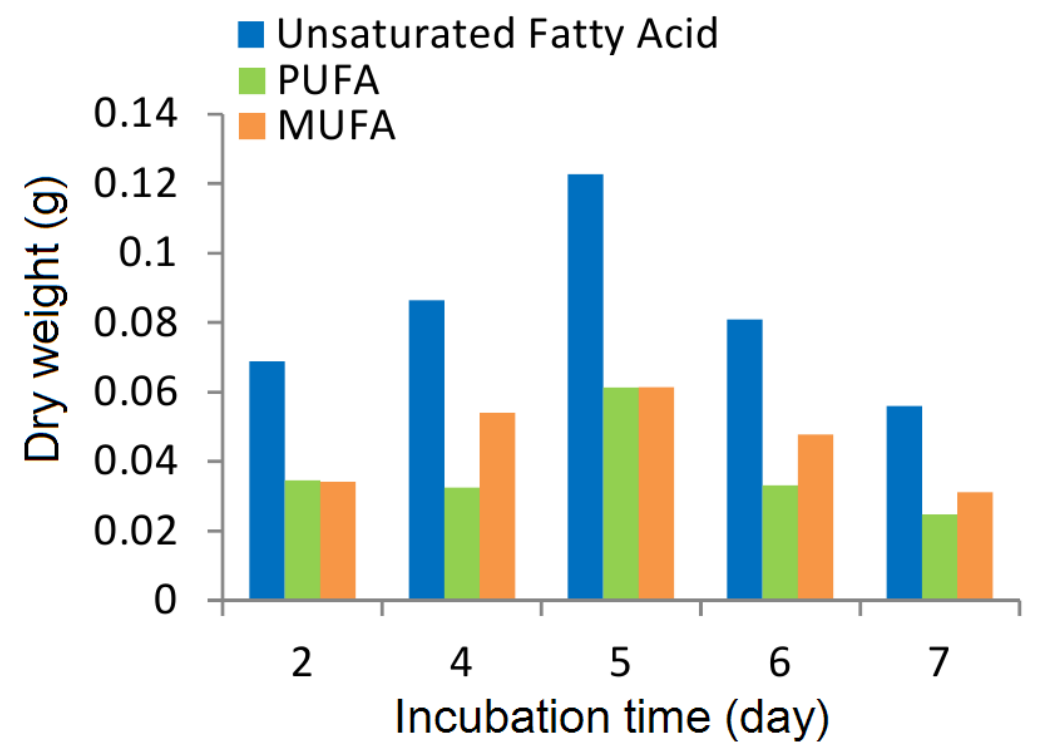

Gambar 10. Pengaruh Waktu Inkubasi pada Bobot Kering Asam Lemak 


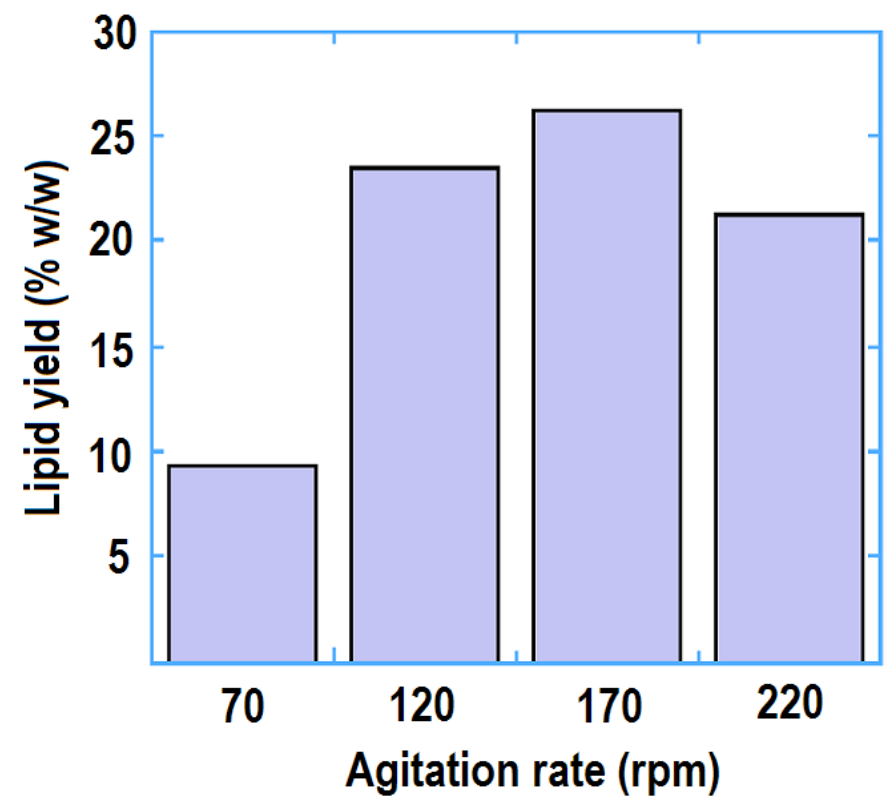

Gambar 11. Pengaruh Laju Agitasi Pada Perolehan Asam Lemak

DAFTAR PUSTAKA

Abu-Elreesh G. \& D. Abd-El-Haleem. 2013. An effective lipidproducing fungal $\mathrm{sp}$. strain DGB 1 and its use for biodiesel production. African Journal of Biotechnology. Vol.12(34):5347-5353

AgroBisnisInfo.com. 2015. Kandungan nutrisi onggok http://www.agrobisnisinfo.com 2015/03/kandungan-nutrisionggok.html

[Diunduh pada 16 Januari 2020]

Annenberg Foundation. 2017. Chemistry: challenges and solutions. Harvard-

Smithsonian Centre for Astrophysics https://www.learner.org/cours es/chemistry

[Diunduh pada 13 Oktober 2018]
Arcanggi A.R.P., P. Arum, A. Rafif \& A. Eka. 2018. Tapioca and tofu waste utilization to produce AA, DHA and EPA. IOP Conference Series: Earth and Environmental Science (105):1-10

Geeshani. 2016. Difference between omega-3, -6 , and -9 http://pediaa.com/differencebetween-omega-3-6-and-9/ [Diunduh pada 11 Oktober 2018]

Guo W., Y. Zhu, Y. Han, Y. Wei \& B. Luo. 2017. Separation mechanism of fatty acid from waste cooking oil and its flotation performance in iron ore desiliconization. Minerals. Vol. 7(244):1-14

Hamam F. \& F. Shahidi. 2008. Incorporation of selected longchain fatty acid into trilinolein and trilinolenin. Food Chemistry (106):33-39 
Kapoor R. \& U. Patil. 2011. Importance and production of omega-3 fatty acids from natural resources. International Food Research Journal (18):491-497

Kawid Kapan. 2013. Onggok dari limbah menjadi peluang bisnis https://kawidkapan.blogspot.c om/2013/05/onggok-darilimbah-menjadi-peluang.html [Diunduh pada 15 Oktober 2018]

Mustika R., A.A. Nugraha, K. Barnita. 2009. Pemanfaatan onggok singkong sebagai sumber asam laktat dalam pembuatan bioplastik kemasan makanan. Institut Pertanian Bogor

Patil D. 2014. Recent trend in production of polyunsaturated fatty acids (PUFA) concentrates: review article. Journal of Food Research and Technology. Vol.2(1):15-23

Patil D. \& A. Nag. 2011. Production of PUFA concentrates from poultry and fish processing waste. Journal of the American Oil Chemist's Society (88): 589-593

Pinasthika N.P., R. Arbianti, T.S. Utami \& $H$. Hermansyah. 2018. Effect of medium and incubation time on production of $A A, D H A$ and EPA from Aspergillus oryzae by solid state fermentation. IOP Conference Series: Earth and Environmental Science (105):1-6

Putri L.R.K., R. Arbianti, T.S. Utami \& H. Hermansyah. 2016. Produksi PUFA dari Aspergillus oryzae berbasis onggok dan ampas tahu dengan variasi konsentrasi karbon dan rasio karbonnitrogen. Proceeding Seminar Nasional Teknik Kimia Teknologi Oleo Petro Kimia Indonesia, Pekan Baru 1 - 2 Oktober 2016:123-132

Rubio-Roriguez N., S. Beltran, I. Jaime, S.M. de Diego, M.T. Sanz \& J.R. Carballido. 2010. Production of omega-3 polyunsaturated fatty acid concentrates: a review. Innovative Food Science and Emerging Technologies (11): $1-12$

Shahidi F. \& U.N. Wanasundara. 1998. Omega-3 fatty acid concentrates: nutritional aspects and production technologies. Trends in Food Science \& Technology. Vol.9(6):230-240

Sumanti D.M., C. Tjahyadi, M. Herudiyanto \& T. Sukarti. 2005. Mekanisme produksi minyak sel tunggal dengan sistem fermentasi padat pada media onggok-ampas tahu dengan menggunakan kapang aspergillus terreus. Jurnal Teknologi dan Industri Pangan Vol.XVI(1):51-61

The Aspergillus Website. 2018. Aspergillus and aspergillosis https://www.aspergillus.org.uk I [Diunduh pada 14 Oktober 2018]

Wikipedia. 2018. Polyunsaturated fatty acids.

https://en.wikipedia.org/wiki/P olyunsaturated fatty acid\#Co njugated fatty acids [Diunduh pada 15 Oktober 2018] 